\title{
EFEKTIVITAS EDUKASI MELALUI APLIKASI MPASI TERHADAP PENGETAHUAN IBU
}

\author{
Rezah Andriani, Inge Anggi Anggarini, Frenalia Valeri Valencia \\ Fakultas Ilmu Kesehatan IKesT Muhammadiyah Palembang \\ Email:ahsanalmaisan@gmail.com
}

\begin{abstract}
Mother's awareness and knowledge about good nutrition for children has an important role in maintaining quality of food. So that, we need an educational application about MPASI that helps mothers in accessing information about how to present MPASI properly and correctly. This purpose of the study was to determine the effectiveness of educational through the MP-ASI application on maternal knowledge at PMB Herasdiana and PMB Zuniawati Palembang in 2021. This Study used a quantitative approach, the method used in this study was a quasi-experimental type of pre-post test control group design. The results of this study, the use of education through the MPASI application was 1.5 times more effective than education through leaflets in increasing Mother's knowledge about MPASI with a score of 5. The use of education through the MPASI application was 6.5 times more effective than education through leaflets in increasing Mother's Knowledge about how to give MPASI with a score of 5.5 .
\end{abstract}

Keywords: MPASI, application, knowledge

\section{PENDAhuluan}

Masalah gizi (Kekurangan Energi dan Protein) dan stunting dapat disebabkan oleh kurang tepatnya pemberian MP-ASI (Arifin et al., 2020). MPASI adalah makanan pendamping ASI yang diberikan kepada anak usia 6 bulan sampai 2 tahun untuk memenuhi kebutuhan gizi. WHO dan Kemenkes serta Ikatan Dokter Anak Indonesia (IDAI) menjelaskan bahwa anak sampai usia 6 bulan hanya diberikan ASI eksklusif saja. MPASI baru bisa diberikan ketika bayi berusia 6 bulan keatas (Riksani, 2012).

MP-ASI dikatakan baik jika memenuhi syarat tepat waktu, bergizi lengkap, cukup dan seimbang, aman, serta diberikan dengan cara yang benar. Syarat MP-ASI diantaranya adalah padat energi, protein dan zat gizi, tidak berbumbu tajam, tanpa gula dan garam, penyedap rasa, tanpa pewarna dan pengawet buatan, disukai anak, tersedia lokal dan harga terjangkau. Jenis Makanan Pendamping ASI yang tepat diberikan sesuai dengan tahapan usia anak (Keputusan Menteri Kesehatan RI., 2014).

Bayi yang diberikan MP-ASI terlalu dini akan beresiko terkena diare, infeksi saluran napas, alergi, hingga gangguan partumbuhan
(K.H.Brown, K. Dewey, L. Allen, 1998). Nutrisi yang tidak tepat menyebabkan malnutrisi pada anak yang pada akhirnya dapat meningkatkan angka morbiditas dan mortalitas (Dietz, 2001). Hal ini sesuai dengan penelitian Tessema (2013) bahwa adanya hubungan antara waktu pengenalan MP-ASI pertama kali dengan indikator zscore panjang badan menurut usia $(\mathrm{PB} / \mathrm{U})$ pada anak (Tessema et al., 2013). Sementara itu, penelitian lainnya menyatakan bahwa pola kebiasaan pemberian MP-ASI yang kurang tepat seperti pemberian terlalu dini atau terlalu lama, kurang tepatnya porsi dan frekuensi pemberianan makanan dapat menyebabkan masalah gizi (Maseko, M.,\& Owaga, 2012). Penelitian lain juga menunjukkan bahwa pengenalan MP-ASI terlalu dini dapat menyebabkan status gizi kurang pada balita (Widyaswari, 2011).

Hal yang perlu diperhatikan dalam pemberian MP-ASI adalah usia anak, jenis MP-ASI, porsi dan frekuensi, serta cara pemberian MP-ASI (Arifin et al., 2020). MPASI dengan kualitas dan kuantitas yang baik sangat penting karena mengandung sumber gizi makro dan mikro yang berperan dalam pertumbuhan linear anak. Pendidikan dan pengetahuan ibu sangat mempengaruhi 
pengaturan dan kualitas makanan yang diberikan kepada bayi. Kesadaran ibu tentang gizi berperan dalam menjaga kualitas makanan yang diberikan kepada anak (LPPM STIKes Hang Tuah Pekanbaru, 2015). Status gizi bayi dipengaruhi oleh jumlah dan kualitas MPASI (Roger et al., 2001).

Petugas kesehatan sangat berperan dalam memberikan informasi tentang pemberian MPASI yang baik untuk anak usia 6 bulan-24 bulan kepada ibu, pengasuh dan keluarga. Sebuah penelitian menunjukkan ada perbedaan yang bermakna terhadap tumbuh kembang anak setelah mendapatkan penyuluhan dan simulasi MP-ASI selama 2 bulan di Bogor (Chandradewi et al., 2012).

Penelitian dengan intervensi pemberian Makanan Pendamping ASI pada anak usia 624 bulan disertai dengan edukasi kepada ibu berupa penyuluhan yang dilakukan selama 2 minggu menunjukkan perubahan status gizi pada anak. Pemberian edukasi/ pendidikan berupa penyuluhan gizi mempunyai pengaruh terhadap pola pikir dan tingkat kepedulian ibu untuk memberikan asupan makanan yang baik pada anaknya (Chandradewi et al., 2012).

Pengetahuan dan sikap ibu berperan dalam pemberian MP-ASI (Adiningsih, 2010). Pengetahuan ibu dapat meningkatkan status kesehatan dan gizi anak. (Gichana, 2013). Pengetahuan akan mempengaruhi sikap seseorang jika diimplementasikan dalam kehidupan sehari-hari (Saaka, 2014). Upaya yang dapat dilakukan untuk meningkatkan pengetahuan ibu yaitu dengan cara edukasi MP-ASI sehingga dapat memperbaiki perilaku ibu dalam memberikan MP-ASI yang tepat, bergizi lengkap, cukup dan seimbang, aman, dan dengan cara yang benar pada anak. (Hestuningtyas T.R, 2015).

Pada penelitian di Karachi, Pakistan mengenai pengaruh edukasi gizi pada ibu tentang MP-ASI terhadap status gizi anak yang dilakukan selama 30 minggu, menunjukan dampak positif pada penambahan berat badan, tinggi badan dan lingkar lengan atas. Pravelensi stunting dan gizi kurang mengalami penurunan sebesar $10 \%$ pada kelompok yang diberikan edukasi. Status gizi anak dipengaruhi oleh pengetahuan dan perilaku ibunya dalam pemberian MP-ASI yang seimbang serta mencukupi kebutuhan gizi anak sehingga dapat mencegah terjadinya malnutrisi (Saleem et al., 2014).

Teknologi digital telah berkembang pesat dan canggih dalam beberapa dekade terakhir, terutama sejak kemunculan internet. Internet merubah kehidupan manusia. Penggunaan aplikasi dalam mengakses pengetahuan dinilai dapat mempermudah masyarakat. Berdasarkan uraian di atas maka perlu dilakukannya penelitian tentang "Efektivitas Edukasi Melalui Aplikasi MP-ASI terhadap Pengetahuan Ibu".

\section{METODE PENELITIAN}

Metode penelitian ini menggunakan pendekatan kuantitatif, dengan quasi eksperimen pre-post test control group design. Tempat penelitian di PMB Herasdiana dan Zuniawati Palembang. Waktu penelitian dilaksanakan dari bulan FebruariJuni 2021.

Variabel dalam penelitian ini terdiri dari variabel terikat yaitu pengetahuan ibu dan variabel bebas yaitu edukasi aplikasi melalui MP-ASI. Populasi yaitu ibu yang memiliki anak usia 6-24 bulan di kota Palembang. Sampel yaitu ibu yang memiliki anak usia 6-24 bulan yang memenuhi kriteria inklusi dan ekslusi berjumlah 30 kelompok perlakuan dan 30 kelompok kontrol di Praktik Mandiri Bidan (PMB) Herasdiana dan Zuniawati. Kriteria inklusi yaitu ibu yang memiliki anak usia 6-24 bulan, bersedia menjadi responden, bertempat tinggal di wilayah kerja PMB Herasdiana dan PMB Zuniawati.

Kriteria eksklusi yaitu ibu yang memiliki anak dalam kondisi sakit, memiliki anak dengan riwayat gangguan pencernaan, serta menggalami infeksi TB berdasarkan anamnesis. Kriteria Drop out yaitu: tidak mengikuti edukasi melalui aplikasi, mengundurkan diri saat penelitian berlangsung, pindah alamat yang tidak diketahui. Teknik pengambilan sampel yaitu purposive sampling. 
Penelitian dimulai dengan menentukan sampel berdasarkan kriteria inklusi dan eksklusi, sampai jumlah sampel terpenuhi sejumlah 30 kelompok perlakuan dan 30 kelompok kontrol. Pada minggu pertama dilakukan pengkajian data berupa pengukuran pengetahuan ibu dengan kuesioner (pengetahuan ibu tentang MPASI dan Pengetahuan ibu tentang cara pemberian MPASI) pada kelompok perlakuan dan kontrol, kemudian pada minggu kedua dilakukan pemberian edukasi aplikasi MP-ASI via smartphone pada ibu kelompok perlakuan, setelah itu dipantau/ diobservasi pemberian MPASI oleh ibu kepada anaknya sampai dengan 2 bulan setelah pemberian edukasi. Sedangkan pada kelompok kontrol diberikan edukasi dengan memberikan leaflet tentang MPASI. Pada akhir penelitian dilakukan pengkajian data ulang mengenai pengetahuan ibu (dengan kuesioner) pada kedua kelompok.

Aplikasi MPASI dibuat berdasarkan fitur yang akan di desain sesuai dengan kebutuhan. Aplikasi tersebut adalah aplikasi yang dapat digunakan dari aplikasi Flash Player. Pemberian edukasi aplikasi MP-ASI diimplementasikan dengan cara memberikan penyuluhan kepada ibu-ibu yang memiliki anak yang sedang MPASI tentang cara penggunaan aplikasi tersebut serta pemahaman dari isi aplikasi tersebut. Selama 2 bulan peneliti mengobservasi dengan lembar observasi tentang kepatuhan ibu dalam memberikan menu makanan dan cara penyajian MPASI kepada anaknya. Pengukuran pengetahuan ibu menggunakan lembar kuesioner. Uji statistik yang digunakan yaitu t-test dengan $95 \%$ confidence interval.

\section{HASIL DAN PEMBAHASAN}

Aplikasi Makanan Pendamping ASI (MPASI) dibuat dan didesain oleh ahli bidang Sistem Informasi dan Dosen Kebidanan yang sudah tersertifikasi sebagai konselor Makanan Pendamping ASI yang dibuktikan dengan sertifikat Pelatihan Konselor MPASI. Aplikasi ini dapat digunakan melalui smartphone maupun laptop ataupun komputer, jika melalui smartphone pengguna harus mendownload

adobe flash terlebih dahulu. Aplikasi ini telah diujikan pada 10 orang responden untuk melihat testimoni atau kepuasan responden terhadap kemudahan mengakses aplikasi tersebut sebelum diujikan pada subjek penelitian yang sebenarnya. Hasil testimoni tersebut yaitu sebanyak $80 \%$ responden mengatakan dapat mengakses aplikasi tersebut dengan mudah, 90\% responden mengatakan dapat mengerti atau memahami isi aplikasi tersebut, $80 \%$ responden mengatakan puas terhadap aplikasi tersebut.

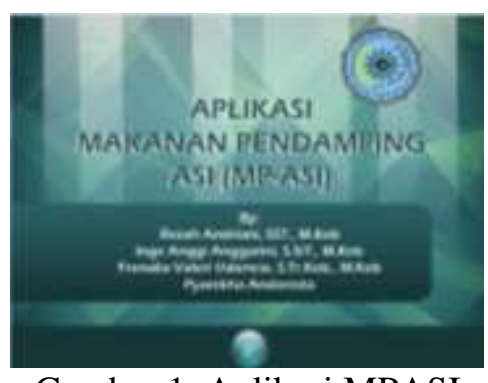

Gambar 1. Aplikasi MPASI

Karakteristik subjek penelitian disajikan untuk mengetahui keseragaman antara kelompok perlakuan dan kontrol pada awal penelitian. Kedua kelompok penelitian dibandingkan yaitu usia anak, usia ibu, jenis kelamin anak, pendidikan ibu, paritas, pekerjaan ibu:

Tabel 1. Karakteristik Subjek Penelitian

\begin{tabular}{llcc} 
& \multicolumn{2}{c}{ Kelompok } & \multirow{2}{*}{ Nilai } \\
\cline { 2 - 3 } Karakteristik & $\begin{array}{c}\text { Perlakuan } \\
(\mathbf{n = 3 0})\end{array}$ & $\begin{array}{c}\text { Kontrol } \\
(\mathbf{n = 3 0})\end{array}$ & $\mathbf{p}^{*)}$ \\
\hline $\begin{array}{l}\text { Usia anak } \\
\text { (bln) }\end{array}$ & & & 0,954 \\
6-8 bulan & 15 & 14 & \\
9-11 bulan & 8 & 9 & \\
12-24 bulan & 7 & 7 & \\
& & & \\
2. Usia Ibu (thn) & & & 0,940 \\
17-20 tahun & 8 & 9 & \\
21-25 tahun & 11 & 9 & \\
26-30 tahun & 8 & 8 & \\
31-35 tahun & 3 & 4 & \\
3. Jenis & & & \\
Kelamin & & & \\
anak & & 17 & \\
Laki-laki & 16 & 13 & \\
Perempuan & 14 & & \\
4. & & &
\end{tabular}

4. 
5. Pendidikan

0,877

Ibu

SD

SMP

SMA

Diploma-

Sarjana

6. Paritas

Primigravida

Multigravida

7. Pekerjaan

Ibu

Tidak Bekerja

Bekerja

Keterangan: ${ }^{*}$ Uji chi kuadrat

Tabel 1 menyatakan pada kelompok perlakuan subjek penelitian yang mempunyai anak berusia paling banyak pada usia 6-8 bulan (15 orang) lebih banyak dari pada usia 9-11 bulan (8 orang) dan 12-24 bulan (7 orang), pada kelompok kontrol subjek penelitian yang mempunyai anak berusia 6-8 bulan (14 orang) lebih banyak dari pada usia 9-11 bulan (9 orang) dan 12-24 bulan (7 orang). Subjek Penelitian pada kelompok perlakuan yang berusia 21-25 tahun (11 orang) lebih banyak dari yang berusia 17-20 tahun dan 26-30 tahun (masing-masing 8 orang) serta yang berusia 31-35 tahun (3 orang), Sedangkan pada kelompok kontrol yang berusia 17-20 tahun dan 21-25 tahun (masing-masing 9 orang) lebih banyak dari pada yang berusia 26-30 tahun (8 orang) dan 31-35 tahun (4 orang). Subjek penelitian yang memiliki anak dengan jenis kelamin laki-laki pada kelompok perlakuan (16 orang) lebih banyak dari pada jenis kelamin perempuan (14 orang), pada kelompok kontrol subjek penelitian yang memiliki anak dengan jenis kelamin laki-laki (17 orang) lebih banyak dari pada jenis kelamin perempuan (13 orang).

Pendidikan Ibu pada kelompok perlakuan lebih banyak yang berpendidikan SMP dan SMA (masing-masing 9 orang) dari pada lulusan SD (7 orang) dan Diploma-Sarjana (5 orang). Sedangkan pada kelompok kontrol ibu yang berpendidikan SMA (11 orang) lebih banyak dari pada SD, SMP, dan DiplomaSarjana (masing-masing 5, 8 dan 6 orang). Subjek penelitian baik pada kelompok perlakuan maupun pada kelompok kontrol yang merupakan multigravida (16 dan 18 orang) lebih banyak dibandingkan primigravida (14 dan 12 orang). Subjek penelitian pada kelompok perlakuan lebih banyak yang tidak bekerja (16 orang) dari pada yang bekerja (14 orang), sedangkan pada kelompok kontrol subjek penelitian yang bekerja (17 orang) lebih banyak dari pada yang tidak bekerja (13 orang).

Secara statistik tidak ada perbedaan yang bermakna antara kedua kelompok penelitian dalam hal usia anak, usia ibu, jenis kelamin anak, pendidikan ibu, paritas, dan pekerjaan ibu (p>0,05).

Tabel 2. Analisis Perbedaan Pengetahuan Ibu tentang MPASI Sebelum dan Setelah Intervensi pada Kelompok Perlakuan dan Kelompok Kontrol

\begin{tabular}{llll}
\hline $\begin{array}{c}\text { Pengetahuan Ibu } \\
\text { tentang MPASI }\end{array}$ & $\begin{array}{c}\text { Kelompok } \\
\text { Perlakuan } \\
(\mathbf{n = 3 0})\end{array}$ & $\begin{array}{c}\text { Kontrol } \\
(\mathbf{n = 3 0})\end{array}$ & $\begin{array}{c}\text { Nilai } \\
\mathbf{p}\end{array}$ \\
\hline 1. Pengetahuan & & & 0,875 \\
$\quad$ Ibu tentang & & & $\left.{ }^{*}\right)$ \\
$\quad$ MPASI Pre & & & \\
x (SD) & $10,3(4,2)$ & $10,2(3,9)$ & \\
Median & 9 & 10 & \\
Rentang & $5-17$ & $5-17$ &
\end{tabular}

2. Pengetahuan Ibu tentang 0,012 MPASI Post

\begin{tabular}{lll}
$\mathrm{x}(\mathrm{SD})$ & $16,5(2,7)$ & $14,2(3,5)$ \\
Median & 17 & 15 \\
Rentang & $10-20$ & $8-20$ \\
\hline $\begin{array}{l}\text { Perbandingan } \\
\text { pre } \text { vs post }\end{array}$ & $\left.0,000^{* *}\right)$ & $0,000^{* *)}$ \\
\hline
\end{tabular}

Nilai p

Keterangan: *) Uji Mann-Whitney, ${ }^{* *}$ Uji Wilcoxon

Tabel 2 menunjukkan bahwa pada awal penelitian (pre) rerata Pengetahuan Ibu tentang MPASI pada kelompok perlakuan $(10,3)$ hampir sama dengan kelompok kontrol $(10,2)$, sedangkan pada akhir penelitian (post) rerata Pengetahuan Ibu tentang MPASI pada kelompok perlakuan lebih tinggi $(16,5)$ dibandingkan pada kelompok kontrol $(14,2)$. Tabel 2 menunjukkan bahwa pada kelompok perlakuan maupun kelompok kontrol masingmasing terdapat perbedaan yang bermakna antara Pengetahuan Ibu tentang MPASI sebelum dan setelah intervensi $\mathrm{p}<0,05$. Tabel 
2 juga menunjukkan bahwa tidak ada perbedaan yang bermakna pada Pengetahuan Ibu tentang MPASI sebelum intervensi (pre) antara kelompok perlakuan dan kelompok kontrol $(p>0,05)$. Terdapat perbedaan yang bermakna pada Pengetahuan Ibu tentang MPASI setelah intervensi (post) antara kelompok perlakuan dan kelompok kontrol $\mathrm{p}<0,05$.

Tidak adanya perbedaan yang bermakna pada pengetahuan ibu tentang MPASI pre dikarenakan kurangnya informasi dan pengetahuan yang didapatkan oleh ibu mengenai MP-ASI. Hal ini sesuai dengan penelitian Heryanto (2017) bahwa ada hubungan pemberian ASI dini dengan pengetahuan ( $p$ value 0,017). Pengetahuan merupakan hasil dari tahu dan ini terjadi setelah orang melakukan penginderaan terhadap suatu objek tertentu. (Notoatmodjo, 2014). Pemberian MP-ASI yang salah dapat menimbulkan gangguan pencernaan dan status gizi pada anak. Sehingga, pengetahuan mengenai MP-ASI penting untuk dipahami para ibu. Pengetahuan tentang MP-ASI dipengaruhi oleh faktor-faktor seperti umur, tingkat pendidikan, pengalaman, lingkungan/ sosial budaya. Pengetahuan ibu juga dipengaruhi oleh sumber informasi baik dari mitos atau media massa (Indriani Nasution et al., 2016). Peningkatkan pengetahuan dapat dilakukan melalui edukasi. Salah satu edukasi yang dapat diberikan kepada ibu adalah edukasi gizi mengenai MP-ASI. Tujuan edukasi yaitu untuk meningkatkan pengetahuan ibu guna untuk memenuhi gizi anak. Hasil penelitian (Manikyamba D. et al., 2015) menyatakan bahwa ada pengaruh pemberian edukasi gizi terhadap pengetahuan ibu tentang pemberian MP-ASI (Manikyamba D. et al., 2015).

Edukasi yang diberikan pada penelitian ini adalah media leaflet dan aplikasi MP-ASI. Leaflet adalah selembar kertas yang memuat informasi disertai gambar yang jelas dan menarik. Leaflet dapat menjadi pelengkap materi utama serta mudah dibagikan dan memungkinkan pembaca mendapat informasi mengenai topik sensitive. Hasil penelitian (Ramadhanti et al., 2019) menyatakan bahwa ada peningkatan pengetahuan dan sikap ibu terhadap tumbuh kembang balita dengan menggunakan metode penyuluhan berupa media leaflet dibandingkan metode penyuluhan tanpa media leaflet. Sedangkan aplikasi MP-ASI adalah aplikasi yang merupakan media audiovisual karena didalam menu aplikasi tersebut terdapat video, gambar serta penjelasan mengenai informasi cara pemberian MP-ASI yang benar dan tepat. media audiovisual adalah media yang berunsur audio dan gambar yang dibuat guna secara jelas dan menarik. Media audiovisual dapat dipergunakan berulang kali. media audiovisual sangat efektif dalam pemberian informasi kepada setiap orang. Hal ini sejalan dengan penelitian (Dipo Wicaksono, 2016) menjelaskan bahwa media audiovisual merupakan media yang memiliki peranan terhadap peningkatan pengetahuan, sikap, dan perilaku ibu baduta tentang MPASI. Dapat disimpulkan bahwa leaflet dan aplikasi MP-ASI dapat meningkatkan pengetahuan ibu mengenai MP-ASI. Hal ini sesuai dengan penelitian yang didapatkan hasil bahwa terdapat perbedaan yang bermakna pada Pengetahuan Ibu tentang MPASI setelah intervensi (post) antara kelompok perlakuan dan kelompok kontrol $\mathrm{p}<0,05$.

Tabel 3. Analisis Perbedaan Selisih Pengetahuan Ibu tentang MPASI Sebelum dan Setelah Intervensi pada Kelompok Perlakuan dan Kelompok Kontrol

\begin{tabular}{lccc}
\hline \multicolumn{1}{c}{$\begin{array}{c}\text { Selisih } \\
\text { Pengetahuan } \\
\text { Ibu tentang }\end{array}$} & \multicolumn{2}{c}{ Kelompok } & Perlakuan \\
\cline { 2 - 3 }$\quad$ MPASI & $(\mathbf{n = 3 0 )}$ & $\begin{array}{c}\text { Kontrol } \\
(\mathbf{n}=30)\end{array}$ & $\begin{array}{c}\text { Nilai } \\
\left.\mathbf{p}^{*}\right)\end{array}$ \\
\hline $\begin{array}{l}\text { Selisih } \\
\text { Pengetahuan }\end{array}$ & & & 0,001 \\
$\begin{array}{l}\text { Ibu tentang } \\
\text { MPASI }\end{array}$ & & & \\
X (SD) & $6,1(2,5)$ & $4,0(1,4)$ & \\
Median & 7 & 4,5 & \\
Rentang & $1-10$ & $2-7$ & \\
\hline
\end{tabular}

Keterangan: *) Uji Mann-Whitney 
Tabel 3 menunjukkan rata-rata selisih Pengetahuan Ibu tentang MPASI pada kelompok perlakuan $(6,1)$ lebih tinggi dibandingkan pada kelompok kontrol $(4,0)$. Secara statistik terdapat perbedaan yang bermakna pada selisih Pengetahuan Ibu tentang MPASI sebelum dan setelah dilakukannya intervensi antara kelompok perlakuan dan kelompok kontrol $\mathrm{p}<0,05$. Pengetahuan ibu tentang MP-ASI pada kelompok yang diberikan intervensi aplikasi MP-ASI lebih efektif dibandingkan kelompok yang diberikan intevensi leaflet. Hal ini dikarenakan pada aplikasi MP-ASI merupakan aplikasi yang mudah untuk dipahami dan dimengerti. Aplikasi MP-ASI ini dilengkapi dengan video mengenai resep MP-ASI, informasi mengenai gizi seimbang, tinggi badan dan berat badan yang sesuai dengan standar sehingga ibu bisa memberikan MP-ASI yang tepat, benar dan aman untuk anaknya sedangkan leaflet hanya berisikan informasi saja tanpa video penjelasan.

\section{Tabel 4. Analisis Efektivitas Edukasi melalui Aplikasi MP-ASI terhadap Pengetahuan Ibu tentang MPASI}

\begin{tabular}{|c|c|c|c|c|}
\hline \multirow[t]{2}{*}{ Kelompk } & \multicolumn{2}{|c|}{$\begin{array}{c}\text { Pengetahuan Ibu } \\
\text { tentang MPASI }\end{array}$} & \multirow{2}{*}{$\begin{array}{c}\text { Nilai } \\
\left.\mathbf{p}^{*}\right)\end{array}$} & \multirow{2}{*}{$\begin{array}{c}\text { RR (IK } \\
95 \%)\end{array}$} \\
\hline & $<5$ & $\geq 5$ & & \\
\hline $\begin{array}{l}\text { Kontrol } \\
\text { Perlakuan }\end{array}$ & $\begin{array}{c}15(68,2 \%) \\
7(31,8 \%)\end{array}$ & $\begin{array}{l}15(39,5 \%) \\
23(60,5 \%)\end{array}$ & 0,032 & \\
\hline
\end{tabular}

\section{Keterangan: RR (IK 95\%): Risiko Relatif dan Interval Kepercayaan 95\%, ") Uji Chi Kuadrat}

Tabel 4 menyatakan bahwa pada kelompok perlakuan subjek penelitian yang mengalami peningkatan Pengetahuan Ibu tentang MPASI dengan skor $\geq 5$ (60,5\%) lebih banyak dibandingkan pada kelompok kontrol $(39,5 \%)$. Sedangkan subjek penelitian yang mengalami peningkatan Pengetahuan Ibu tentang MPASI dengan skor $<5$ lebih banyak pada kelompok kontrol $(68,2 \%)$ dibandingkan pada kelompok perlakuan $(31,8 \%)$. Sehingga ibu yang mendapatkan edukasi melalui aplikasi MPASI memiliki peluang mengalami peningkatan Pengetahuan Ibu tentang MPASI dengan skor $\geq 5$ sebesar 1,5 kali lebih besar dibandingkan dengan ibu yang hanya mendapatkan edukasi melalui leaflet. Atau dengan kata lain penggunaan edukasi melalui aplikasi MPASI lebih efektif 1,5 kali dari pada edukasi melalui leaflet dalam meningkatkan Pengetahuan Ibu tentang MPASI dengan skor $\geq 5$.

Pengetahuan ibu sangat penting dalam pemberian MP-ASI. Pemberian MP-ASI pada bayi sebagian besar ditentukan oleh tindakan ibu yang dibentuk dari pengetahuan dan sikap ibu, tindakan ini dipengaruhi oleh karakteristik ibu. (Firdhani \& Gunanti, 2012). Ibu sangat berperan dalam menyusun pola pemberian makanan bagi bayinya, mulai dari menentukan, memilih, mengolah, menyajikan sampai memberikan menu. Pengetahuan ibu terhadap MP-ASI mempengaruhi perilaku ibu dalam pemberian MP-ASI, dari segi ketepatan waktu, jenis makanan, konsistensi makanan, maupun jumlah makanan. (Kusumasari, 2012). Status gizi anak akan terbentuk apabila ibu memiliki pengetahuan yang baik mengenai MP-ASI.

Upaya yang dapat dilakukan untuk memperbaiki pengetahuan dan perilaku ibu dapat dilakukan dengan penyuluhan. Seorang ibu sangat berperan dalam pengaturan menu 95\%) di dalam rumah tangga. Penyuluhan dilakukan guna untuk memberikan edukasi kepada ibu mengenai pemberian MP-ASI. Pelaksanaan edukasi MP-ASI pada ibu yang memiliki bayi diharapkan dapat meningkatkan pengetahuan ibu sehingga ibu dapat memberikan MP-ASI secara tepat (Ahmad et al., 2019). Namun dalam pemberian edukasi melalui Penyuluhan MPASI membutuhkan media agar informasi yang ditransfer mudah diterima oleh para ibu. Media dibutuhkan untuk mengatasi permasalahan yang biasa ditemukan dalam penyuluhan (Depkes RI, 2014). Dalam penelitian ini media yang digunakan dalam pemberian edukasi mengenai MP-ASI menggunakan leaflet dan aplikasi MP-ASI.

Leaflet merupakan media berbentuk selembaran kertas yang memuat gambar dan tulisan yang dirangkai menjadi informasi yang sifatnya ringkas dan jelas serta memudahkan setiap orang untuk bisa memahami informasi yang diberikan. 
Informasi yang ada didalam leaflet menggunakan tata bahasa yang mudah dimengerti, judul yang terdapat dalam leaflet dibuat menarik serta dapat dipadukan dengan gambar-gambar yang berkaitan dengan isi leaflet. Isi harus disesuaikan dengan sasaran yang akan diberikan intervensi (Yulianti D, Yudha KE, 2011).

Aplikasi MP-ASI adalah aplikasi yang dirancang dengan menampilkan informasi mengenai pemberian MP-ASI. Pengetahuan pemberian MP-ASI aplikasi ini disajikan dalam 6 menu yaitu mengenai standar penilaian status gizi anak, rekomendasi WHO optimal feeding pada bayi dan anak, pedoman pemberian makanan pada bayi/anak usia 6-24 bulan, MPASI 4 menu bintang, indikator bayi siap menerima MP-ASI, dan dampak pemberian MP-ASI terlalu dini dan terlalu lambat. Aplikasi ini sangat mudah untuk digunakan dan dipahami oleh ibu-ibu. Aplikasi ini dapat dikirim ke pengguna android lain melalui Bluetooth atau aplikasi berbagi berkas seperti shareit. Selain itu aplikasi MP-ASI dapat digunakan dimana saja, kapan saja, dan dapat digunakan berulang kali.

Berdasarkan hasil penelitian didapatkan hasil bahwa edukasi menggunakan aplikasi lebih efektif dibandingkan dengan leaflet. Hal ini dikarenakan ketika mengakses aplikasi MPASI melibatkan berbagai alat indera, seperti penglihatan dan pendengaran. Semakin banyak pancaindera yang digunakan, semakin mudah masuknya informasi. Hal ini sesuai dengan teori yang dikemukakan oleh (Listyarini \& Hindriyastuti, 2017), bahwa 75\%-87\% seseorang meningkatkan pengetahuannya dengan melihat atau diperoleh dari pancaindera. Teori yang dikemukakan oleh (Maulana, 2014) juga mengatkan hal yang sama, bahwa pancaindera yang paling banyak menyalurkan pengetahuan ke otak adalah mata (sekitar 75\%-87\%), sedangkan 13\%-25\% pengetahuan manusia diperoleh dan disalurkan melalui pancaindera yang lain. Sesuai penelitian yang dilakukan oleh (Mey et al., 2020) yang mendapatkan hasil bahwa Terdapat pengaruh penerapan aplikasi EDIFO dalam meningkatkan pengetahuan secara bermakna dibandingkan dengan metode penyuluhan. Hal ini membuktikan bahwa penggunaan aplikasi lebih efektif dibandingkan leaflet.

Tabel 5. Analisis Perbedaan Pengetahuan Ibu tentang Cara Pemberian MPASI Sebelum dan Setelah Intervensi pada Kelompok Perlakuan dan Kelompok Kontrol

\begin{tabular}{llll}
\hline \multirow{2}{*}{$\begin{array}{c}\text { Pengetahuan Ibu } \\
\text { tentang cara } \\
\text { pemberian MPASI }\end{array}$} & \multicolumn{2}{c}{ Kelompok } & \\
\cline { 2 - 3 } & $\begin{array}{c}\text { Perlakuan } \\
(\mathbf{n}=30)\end{array}$ & $\begin{array}{c}\text { Kontrol } \\
(\mathbf{n}=30)\end{array}$ & Nilai p \\
\hline 1. $\begin{array}{l}\text { Pengetahuan } \\
\text { Ibu tentang } \\
\text { cara }\end{array}$ & & & $\left.0,852^{*}\right)$ \\
pemberian & & & \\
MPASI Pre & & & \\
X (SD) & $8,3(3,4)$ & $8,6(3,7)$ & \\
Median & 7,5 & 7 & \\
Rentang & $3-15$ & $3-17$ & \\
\end{tabular}

2. Pengetahuan $\left.0,000^{*}\right)$

Ibu tentang

cara pemberian MPASI Post $\mathrm{x}(\mathrm{SD}) \quad 16,5(3,1) \quad 12,5(3,5)$ $\begin{array}{lll}\text { Median } & 17 & 12\end{array}$

Rentang $\quad 10-20 \quad 7-20$

Perbandingan pre $0,000^{* *)} \quad 0,000^{* * *}$ vs post

Nilai p Keterangan: *) Uji Mann-Whitney, ${ }^{* * *} \quad$ Uji Wilcoxon

Tabel 5 menunjukkan bahwa pada awal penelitian (pre) rerata Pengetahuan Ibu tentang cara pemberian MPASI pada kelompok kontrol $(8,6)$ hampir sama dengan kelompok perlakuan $(8,3)$, sedangkan pada akhir penelitian (post) rerata Pengetahuan Ibu tentang cara pemberian MPASI pada kelompok perlakuan lebih tinggi $(16,5)$ dibandingkan pada kelompok kontrol $(12,5)$. Tabel 5 menunjukkan bahwa pada kelompok perlakuan maupun kelompok kontrol masingmasing terdapat perbedaan yang bermakna antara Pengetahuan Ibu tentang cara pemberian MPASI sebelum dan setelah intervensi $p<0,05$. Tabel 5 juga menunjukkan bahwa tidak ada perbedaan yang bermakna pada Pengetahuan Ibu tentang cara pemberian MPASI sebelum intervensi (pre) antara kelompok perlakuan dan kelompok 
kontrol $(\mathrm{p}>0,05)$. Terdapat perbedaan yang bermakna pada Pengetahuan Ibu tentang cara pemberian MPASI setelah intervensi (post) antara kelompok perlakuan dan kelompok kontrol $\mathrm{p}<0,05$.

Berdasarkan hasil penelitian didapatkan bahwa tidak terdapat perbedaan pengetahuan ibu mengenai cara pemberian MP-ASI antara kelompok perlakuan dan kelompok kontrol. Hal ini dikarenakan pengetahuan ibu mengenai cara pemberian MP-ASI yang kurang tepat. Pemberian ASI yang tepat adalah memenuhi persyaratan tepat waktu, adekuat, aman, dan diberikan dengan cara yang benar. Beberapa faktor yang dapat mempengaruhi cara pemberian MP-ASI seperti pengalaman ibu, kebiasaan keluarga, budaya serta social ekonomi (Pak-Gorstein et al., 2009). Faktor lainnya yang mempengaruhi pemberian MPASI meliputi pendidikan ibu, pendapatan, dan dukungan serta tradisi (Afriyani et al., 2016). Pengetahuan ibu merupakan salah satu faktor yang paling berpengaruh terhadap pemberian MP-ASI. Hal ini sesuai dengan penelitian (Lanou et al., 2019) di Burkina Faso menemukan bahwa terjadi penurunan tren pada praktik pemberian ASI, pemberian makanan padat, semi padat atau lunak yang tepat waktu, dan frekuensi pemberian MP-ASI. Penurunan tren tersebut berkontribusi terhadap meningkatnya pravelensi masalah berat badan seperti stunting, wasting, dan underweight (Lanou et al., 2019).

Hasil penelitian didapatkan bahwa terdapat perbedaan pengetahuan ibu mengenai cara pemberian MP-ASI setelah intervensi pada kelompok perlakuan dan kelompok kontrol. Hal ini menunjukkan bahwa pemberian intervensi baik leaflet maupun aplikasi MP-ASI memberikan pengaruh yang baik terhadap pengetahuan ibu mengenai cara pemberian MP-ASI. Jika ibu dapat memberikan MP-ASI dengan tepat akan membantu dalam proses pertumbuhan dan perkembangan anak. Menurut Nasar (2014) waktu untuk memulai pemberian MP-ASI yang tepat bermanfaat bagi pemenuhan kebutuhan nutrisi anak. Frekuensi pemberian makanan secara bertahap dapat memenuhi kebutuhan anak. Leaflet dan aplikasi MP-ASI merupakan salah satu media edukasi yang dapat diberikan kepada ibu untuk memberikan informasi mengenai cara pemberian MP-ASI, berisi materi yang tersusun sistematis dan menggunakan tata bahasa yang mudah dipahami disertai gambar menarik. Hasil penelitian menunjukkan bahwa leaflet memiliki peran dalam peningkatan pengetahuan ibu tentang ASI Eksklusif dan motivasi ibu untuk menyusui secara ekslusif. Sedangkan aplikasi MP-ASI merupakan aplikasi yang dibuat dalam media audiovisual yang merupakan jenis media yang mengandung unsur gambar dan suara sehingga lebih baik dan menarik. Hasil ini sejalan dengan penelitian yang mengidentifikasi bahwa edukasi gizi menggunakan audio visual dapat meningkatkan pengetahuan ibu tentang pemberian makan pada bayi dan anak (Fitri \& Esem, 2020), karena media audio visual menampilkan gerak, gambar dan suara yang lebih menarik dan tidak monoton dibandingkan dalam bentuk leaflet

Tabel 6. Analisis Perbedaan Selisih Pengetahuan Ibu tentang Cara Pemberian MPASI Sebelum dan Setelah Intervensi pada Kelompok Perlakuan dan Kelompok Kontrol

\begin{tabular}{|c|c|c|c|}
\hline \multirow{2}{*}{$\begin{array}{c}\text { Selisih Pengetahuan } \\
\text { Ibu Tentang Cara } \\
\text { Pemberian MPASI }\end{array}$} & \multicolumn{2}{|c|}{ Kelompok } & \multirow[b]{2}{*}{$\begin{array}{c}\text { Nilai } \\
\mathbf{p}^{*)}\end{array}$} \\
\hline & $\begin{array}{c}\text { Perlakuan } \\
(\mathrm{n}=\mathbf{3 0})\end{array}$ & $\begin{array}{r}\text { Kontro } \\
(\mathbf{n = 3 0})\end{array}$ & \\
\hline $\begin{array}{l}\text { Selisih Pengetahuan } \\
\text { Ibu Tentang Cara }\end{array}$ & & & 0,000 \\
\hline $\begin{array}{l}\text { Pemberian MPASI } \\
\mathrm{x}(\mathrm{SD})\end{array}$ & $8,2(2,6)$ & $3,9(1,3)$ & \\
\hline Median & 8 & 4 & \\
\hline Rentang & $3-14$ & $2-8$ & \\
\hline
\end{tabular}

Keterangan: ${ }^{*}$ Uji Mann-Whitney

Tabel 6. menunjukkan rata-rata selisih Pengetahuan Ibu tentang cara pemberian MPASI pada kelompok perlakuan $(8,2)$ lebih besar dibandingkan pada kelompok kontrol $(3,9)$. Secara statistik terdapat perbedaan yang bermakna pada selisih Pengetahuan Ibu tentang cara pemberian MPASI sebelum dan setelah dilakukannya intervensi antara kelompok perlakuan dan kelompok kontrol $\mathrm{p}<0,05$. Aplikasi MP-ASI lebih efektif dibandingkan leaflet dikarenakan aplikasi 
MP-ASI memiliki media audiovisual yang berisikan cara pemberian MP-ASI yang benar serta lebih menarik sehingga ibu dapat mengaplikasikannya di rumah. Selain itu aplikasi MP-ASI memiliki informasi yang banyak didalam aplikasinya seperti MP-ASI 4 menu bintang, Indikator anak yang siap menerima MP-ASI, Dampak MP-ASI yang diberi secara dini dan terlambat, pedoman pemberian makan pada bayi, rekomendasi WHO, Standar penilaian status gizi anak sedangkan leaflet hanya berisi ringkasan informasi dan beberapa gambar. Kelebihan dalam aplikasi MP-ASI ini adalah aplikasi dapat diakses kapanpun, dimanapun dan berulangkali sehingga ibu dapat mempelajarinya secara rutin. Informasiinformasi penting yang berkaitan dengan program kesehatan akan lebih baik jika disampaikan dengan media yang menarik dan baik sehingga akan membekad diingatan seseorang dan masyarakat.

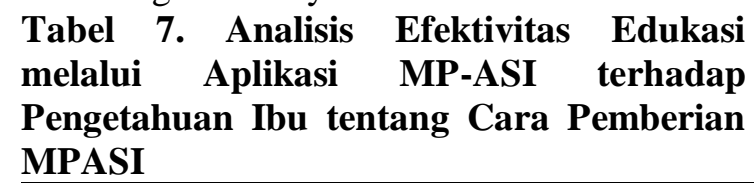

\begin{tabular}{|c|c|c|c|c|}
\hline \multirow[t]{2}{*}{$\begin{array}{c}\text { Kelompo } \\
\mathbf{k}\end{array}$} & \multicolumn{2}{|c|}{$\begin{array}{l}\text { Pengetahuan Ibu } \\
\text { tentang cara } \\
\text { pemberian MPASI }\end{array}$} & \multirow[t]{2}{*}{$\begin{array}{c}\text { Nilai } \\
\mathbf{p}^{*)}\end{array}$} & \multirow[t]{2}{*}{$\begin{array}{c}\text { RR (IK } \\
95 \%)\end{array}$} \\
\hline & $<5,5$ & $\geq 5,5$ & & \\
\hline $\begin{array}{l}\text { Kontrol } \\
\text { Perlakuan }\end{array}$ & $\begin{array}{c}26(86,7 \% \\
) \\
4(13,3 \%)\end{array}$ & $\begin{array}{c}4(13,3 \%) \\
26(86,7 \% \\
)\end{array}$ & $\begin{array}{c}0,00 \\
0\end{array}$ & $\begin{array}{c}6,5(2,5- \\
16,3)\end{array}$ \\
\hline
\end{tabular}

Keterangan: RR (IK 95\%): Risiko Relatif dan Interval Kepercayaan $95 \%,{ }^{*}$ Uji Chi Kuadrat

Tabel 7 menunjukkan bahwa pada kelompok perlakuan subjek penelitian yang mengalami peningkatan Pengetahuan Ibu tentang cara pemberian MPASI dengan skor $\geq 5,5(86,7 \%)$ lebih banyak dibandingkan pada kelompok kontrol (13,3\%). Sedangkan subjek penelitian yang mengalami peningkatan Pengetahuan Ibu tentang cara pemberian MPASI dengan skor $<5,5$ lebih banyak pada kelompok kontrol $(86,7 \%)$ dibandingkan pada kelompok perlakuan $(13,3 \%)$. Sehingga ibu yang mendapatkan edukasi melalui aplikasi MPASI memiliki peluang mengalami peningkatan Pengetahuan Ibu tentang cara pemberian MPASI dengan skor $\geq 5,5$ sebesar
6,5 kali lebih besar dibandingkan dengan ibu yang hanya mendapatkan edukasi melalui leaflet. Atau dengan kata lain penggunaan edukasi melalui aplikasi MPASI lebih efektif 6,5 kali dari pada edukasi melalui leaflet dalam meningkatkan Pengetahuan Ibu tentang cara pemberian MPASI dengan skor $\geq 5,5$.

Pemberian MP-ASI yang optimal sangat penting selama periode 6 bulan samapi 2 tahun baik dari segi bentuk, frekuensi, maupun jumlah dapat mempengaruhi pertumbuhan, perkembangan anak. Oleh karena itu penting untuk memberikan MP-ASI secara optimal (Michaelsen et al., 2017). Hasil penelitian owais didapatkan bahwa praktik pemberian MP-ASI dengan frekuensi yang tepat menghasilkan pertumbuhan anak yang lebih baik pada anak Asia Selatan (Owais et al., 2016). MP-ASI yang optimal didapatkan bila ibu mengetahui cara pemberian MP-ASI yang benar dan tepat. Pemberian MP-ASI yang tepat dalam hal ini harus sesaui dengan usia anak secara frekuensi, kepadatan, dan kekenyalan sangat mempengaruuhi pertumbuhan dan perkembangan anak.

R (IK Pengetahuan merupakan salah satu faktor yang mempengaruhi cara pemberian MP-ASI pada anak. Pengetahuan dipengaruhi oleh beberapa faktor yaitu faktor pendidikan, social budaya dan ekonomi, lingkungan. Pengalaman dan usia, serta informasi/media massa (Dewi Marfuah, 2017).

Edukasi adalah upaya yang dilakukan untuk meningkatkan pengetahuan. Edukasi gizi dapat diberikan untuk merubah perilaku dan pengetahuan ibu mengenai cara pemberian MP-ASI. Proses edukasi gizi dipengaruhi oleh penggunaan alat peraga / media yang mendukung kegiatan edukasi tersebut. Media leaflet dan aplikasi MP-ASI adalah salah media yang dapat digunakan untuk pemberian edukasi mengenai cara pemberian MP-ASI pada anak.

Aplikasi MP-ASI merupakan aplikasi yang dibuat untuk memudahkan ibu dalam persiapan pemberian MP-ASI pada anak. Aplikasi MP-ASI adalah salah satu media yang dapat dijadikan panduan oleh para ibu 
dalam pemberian MP-ASI pada anak. Aplikasi MP-ASI terdapat menu mengenai video mengenai cara pemberian MP-ASI yang benar. Aplikasi MP-ASI merupakan salah satu media yang menggunakan audiovisual yang mengandung unsur suara dan gambar, sehingga pemberian informasi jika lebih jelas dan mudah dimengerti. Menurut (Induniasih \& W. Ratna, 2017), informasi yang berkaitan dengan program kesehatan lebih baik jika disampaikan dengan menarik melalui Media audiovisual yang dikemas secara baik sehingga akan selalu diingat oleh masyarakat. Oleh karena itu aplikasi MP-ASI efektif dalam pemberian edukasi mengenai cara pemberian MP-ASI. Aplikasi MP-ASI juga memiliki kelebihan yaitu mudah diakses, mudah dipahami dan dimengerti, lebih menarik, dapat dilihat berulang kali, dapat digunakan kapan saja dan dimana saja dibandingkan leaflet. Sejalan dengan hasil penelitian yang menunjukkan rata-rata selisih Pengetahuan Ibu tentang cara pemberian MPASI pada kelompok perlakuan $(8,2)$ lebih besar dibandingkan pada kelompok kontrol $(3,9)$. Hal ini sejalan dengan penelitian (Lau et al., 2016) (Lee et al., 2016) yang mengatakan bahwa aplikasi e-technologys dan M-Health dijadikan sebagai alat untuk mendukung program menyusui dan meningkatkan tingkat menyusui. Sehingga dapat disimpulkan bahwa penggunaan aplikasi lebih efektif dibandingkan dengan leaflet.

\section{KESIMPULAN}

Penggunaan edukasi melalui aplikasi MPASI lebih efektif 1,5 kali dari pada edukasi melalui leaflet dalam meningkatkan Pengetahuan Ibu tentang MPASI dengan skor $\geq 5$. Penggunaan edukasi melalui aplikasi MPASI lebih efektif 6,5 kali dari pada edukasi melalui leaflet dalam meningkatkan Pengetahuan Ibu tentang cara pemberian MPASI dengan skor $\geq 5,5$.

\section{REFERENSI}

Adiningsih, S. (2010). Waspadai Gizi Pada Balita Anda. Jakarta: Elex Media Komputindo.
Afriyani, R., Halisa, S., \& Rolina, H. (2016). Faktor-Faktor yang Berhubungan dengan Pemberian MP-ASI pada Bayi Usia 0-6 Bulan di BPM Nurtila Palembang. Jurnal Kesehatan, 7(2), 260. https://doi.org/10.26630/jk.v7i2.198

Ahmad, A., Madanijah, S., Dwiriani, C. M., \& Kolopaking, R. (2019). Pengetahuan, sikap, motivasi ibu, dan praktik pemberian MP-ASI pada anak usia 6-23 bulan: studi formatif di Aceh. Jurnal Gizi Klinik Indonesia, 16(1), 1. https://doi.org/10.22146/ijen.34560

Arifin, Y., Muthia, G., \& Ariyani, F. (2020). Optimalisasi Pengetahuan Ibu Dalam Mencegah Stunting Pada Bayi Usia 624 Bulan Melalui Konseling Gizi. Jurnal Perak Malahayati, 2(1), 8-14.

Chandradewi, A., Darawati, M., \& Salam, A. (2012). Pengaruh Penyuluhan Gizi Terhadap Pola Pemberian MP-ASI, Berat Badan, dan Status Gizi Anak Usia 6-24 Bulan di Kelurahan Selagalas Kota Mataram. Kesehatan Prima, 6(1995), 849-859.

Depkes RI. (2014). Pedoman Gizi Seimbang. Jakarta : Departemen Kesehatan RI.

Dewi Marfuah, I. K. (2017). Upaya Peningkatan Pengetahuan Ibu tentang MP Asi dengan Edukasi Gizi Melalui Booklet. The 6th University Research Colloquium, 273-280. http://journal.ummgl.ac.id/index.php/ur ecol/article/view/1195

Dietz, W. H. (2001). Breastfeeding may help prevent childhood overweight. Journal of the American Medical Association, 285(19), 2506-2507. https://doi.org/10.1001/jama.285.19.250 6

Dipo Wicaksono. (2016). Pengaruh Media Audio-Visual Mp-Asi Terhadap Pengetahuan, Sikap Dan Perilaku Ibu Baduta Di Puskesmas Kelurahan Johar Baru. Ethos Jurnal Penelitan Dan Pengabdian Masyarakat, 4(2), 291298.

Firdhani, A., \& Gunanti, I. (2012). Pola Pemberian Asi, Mp-Asi Dan Status Gizi 
Anak Usia 1-2 Tahun Pada Keluarga Etnis Madura Dan Etnis Arab (Studi di Puskesmas Pegirian dan Puskesmas Perak Timur Surabaya). Buletin Penelitian Sistem Kesehatan, 8(2). https://doi.org/10.22435/bpsk.v8i2

Fitri, H. N., \& Esem, O. (2020). Pendidikan Gizi dengan Audio Visual Meningkatkan. Jurnal Ilmu Kesehatan Masyarakat, 9(4), 200-207.

Gichana, M. B. (2013). Nutritional knowledge of mothers and nutritional status of their children 6-59 months under Melezi bora programme in Kawangware sub location, Dagoretti, Nairobi county. UNIVERSITY OF NAIROBI.

Hestuningtyas T.R, N. E. . (2015). Pengaruh konseling gizi terhadap pengetahuan, sikap, praktik ibu dalam pemberian makan anak, dan asupan zat gizi anak stunting usia 1-2 tahun di kecamtan Semarang timur. Journal of Nutrition College, Volume 3, Nomor 1, Tahun 2014, Halam 12-25. http://ejou. Journal Of Nutrition College, 3(2), 17-25.

Indriani Nasution, S., Liputo, N. I., \& Masri, M. (2016). Faktor-Faktor yang Berhubungan dengan Pola Pemberian ASI Eksklusif di Wilayah Kerja Puskesmas Bungus Tahun 2014. Jurnal Kesehatan Andalas, 5(3), 635-639. https://doi.org/10.25077/jka.v5i3.590

Induniasih \& W. Ratna. (2017). Promosi Kesehatan Pendidikan Kesehatan.

K.H.Brown, K. Dewey, L. Allen. (1998). Breast-feeding and Complementary feeding. Complementary feeding of young children in developing countries: A review of curent scientific knowledge. Geneva : World Health Organization.

Kementerian Kesehatan RI. (2018). Hasil Utama Riskesdas 2018. Jakarta: Balitbang.

https://www.litbang.kemkes.go.id/lapora n-riset-kesehatan-dasar-riskesdas/

Kementerian Kesehatan RI. (2016). Pedoman Pelaksanaan Stimulasi, Deteksi dan Intervensi Dini Tumbuh Kembang Anak. Jakarta : Depkes RI.

Kementerian Kesehatan RI. (2018). Situasi
Balita Pendek (STUNTING) di Indonesia. Jakarta: Buletin Jendela Data dan Informasi Kesehatan. https://www.kemkes.go.id/do wnload.php?file $=$ download $/ \mathrm{p}$ usdatin/buletin/Buletin-

Stunting2018.pdf.

Keputusan Menteri Kesehatan RI. (2011). Standar Antropometri Penilaian Status Gizi Anak. Jakarta: Menkes RI.

Keputusan Menteri Kesehatan RI. (2014). Pedoman Gizi Seimbang. Jakarta: Kemenkes.

Kirana, C., Tommy, L., Wijaya, M. I., Luhur, S. A., Jend, J., Selindung, S., \& Pangkalpinang, L. (2019). Sistem Pakar Diagnosa Penyakit Gizi Buruk Pada Balita Dengan Metode Certainty Factor. E-Jurnal JUSITI (Jurnal Sistem Informasi Dan Teknologi Informasi), 82(2), 141-154. https://doi.org/10.36774/jusiti.v8i2.615

Kusumasari, F. E. (2012). Pendamping Asi Dengan Status Gizi Pada Anak Di Wilayah Kerja Puskesmas Juwiring Klaten. 26-34.

Lanou, H. B., Osendarp, S. J. M., Argaw, A., De Polnay, K., Ouédraogo, C., Kouanda, S., \& Kolsteren, P. (2019). Micronutrient powder supplements combined with nutrition education marginally improve growth amongst children aged 6-23 months in rural Burkina Faso: A cluster randomized controlled trial. Maternal and Child Nutrition, 15(4), 1-13. https://doi.org/10.1111/mcn.12820

Listyarini, A. D., \& Hindriyastuti, S. (2017). Penyuluhan Dengan Media Audio Visual Meningkatkan Perilaku Hidup Bersih Sehat Anak Usia Sekolah. The 5th Urecol Proceeding, February, 112117.

LPPM STIKes Hang Tuah Pekanbaru. (2015). Permasalahan Anak Pendek (Stunting) dan Intervensi untuk Mencegah Terjadinya Stunting (Suatu Kajian Kepustakaan). Jurnal Kesehatan Komunitas, 2(6), 254-261. https://doi.org/10.33085/jkg.v1i3.3952 
Manikyamba D., Vidya D.L., Satyavani A., Krishna Prasa A., \& Tulasi Deepthi K. (2015). Impact of Nutritional Education on the Knowledge of Mothers Regarding Infant and Young Child Feeding Practices. Scholars Journal of Applied Medical Sciences, 3(3A), 1074-1078.

Maseko, M.,\& Owaga, E. (2012). Child Malnutrition And Mortality In Swizeland Situation Analysis Of The Immedate, Underlying And Basic Causes. African Journal of Food, 2(July), 32.

Maulana, H. . (2014). Promosi Kesehatan. Jakarta : EGC.

Mey, D., Ridayani, R., San, N., Kristianto, J., \& Muslim, M. (2020). Penggunaan Media Edukasi Gizi Aplikasi Electronic Diary Food (Edifo) Dan Metode Penyuluhan Serta Pengaruhnya Terhadap Pengetahuan Ibu Hamil. Quality : Jurnal Kesehatan, 14(1), 1-10. https://doi.org/10.36082/qjk.v14i1.93

Michaelsen, K. F., Grummer-Strawn, L., \& Bégin, F. (2017). Emerging issues in complementary feeding: Global aspects. Maternal and Child Nutrition, 13(January), 1-7. https://doi.org/10.1111/mcn.12444

Notoatmodjo. (2014). Metodologi Penelitian Kesehatan. Jakarta : PT. Rineka Cipta.

Owais, A., Schwartz, B., Kleinbaum, D. G., Suchdev, P. S., Faruque, A. S. G., Das, S. K., \& Stein, A. D. (2016). Minimum acceptable diet at 9 months but not exclusive breastfeeding at 3 months or timely complementary feeding initiation is predictive of infant growth in rural Bangladesh. PLoS ONE, 11(10), 1-10. https://doi.org/10.1371/journal.pone.0165 128

Pak-Gorstein, S., Haq, A., \& Graham, E. A. (2009). Cultural influences on infant feeding practices. Pediatrics in Review, 30(3). https://doi.org/10.1542/pir.30-3e11

Ramadhanti, C. A., Adespin, D. A., \& Julianti, H. P. (2019). Perbandingan Penggunaan Metode Penyuluhan Dengan Dan Tanpa Media Leaflet Terhadap Pengetahuan. 8(1), 99-120.
Riksani, R. (2012). Variasi Olahan Makanan Pendamping ASI. Jakarta: Dunia Kreasi.

Roger, S., Caecar G, V., Mercedes, de O., Rosangela, L., Monika, B., \& Graeme, C. (2001). Worldwide timing of growth faltering: implications for nutritional interventions. Pediatrics, 107(5), 5.

Saaka, M. (2014). Relationship between mothers' nutritional knowledge in childcare practices and the growth of children living in impoverished rural communities. Journal of Health, Population and Nutrition, 32(2), 237248.

https://doi.org/10.3329/jhpn.v32i2.2618

Saleem, A. F., Mahmud, S., Baig-Ansari, N., \& Zaidi, A. K. M. (2014). Impact of Maternal Education about Complementary Feeding on Their Infants' Nutritional Outcomes in Lowand Middle-income Households: A Community-based Randomized Interventional Study in Karachi, Pakistan. Journal of Health, Population and Nutrition, 32(4), 623-633. https://doi.org/10.3329/jhpn.v32i4.3019

Tessema, M., Belachew, T., \& Ersino, G. (2013). Feeding patterns and stunting during early childhood in rural communities of Sidama South Ethiopia. Pan African Medical Journal, 14, 1-12. https://doi.org/10.11604/pamj.2013.14. 75.1630

Widyaswari, R. (2011). Hubungan Waktu Pengenalan Makanan Pendamping ASI dengan Status Gizi Pada Bayi Usia 624 Bulan Di Kecamatan Banjarsari Surakarta. Universitas Sebelas Maret Surakarta.

Yulianti D, Yudha KE, H. . (2011). Promosi Kesehatan dalam Praktik Kebidanan. Jakarta : EGC. 